WANDA ZAGÓRSKA (iD orcid.org/0000-0003-2615-9565

Wydział Filozofii Chrześcijańskiej, Uniwersytet Kardynała Stefana Wyszyńskiego, Warszawa Faculty of Christian Philosophy, Cardinal Stefan Wyszynski University, Warsaw e-mail:w.zagorska@uksw.edu.pl

MAGDALENA MAJEWSKA

Wydział Filozofii Chrześcijańskiej, Uniwersytet Kardynała Stefana Wyszyńskiego, Warszawa Faculty of Christian Philosophy, Cardinal Stefan Wyszynski University, Warsaw

\title{
Rozpoznawanie podmiotowych znaczeń. Analiza hermeneutyczna autonarracji osób w późnej dorosłości z zastosowaniem oryginalnej metody interpretacji treści
}

\section{Recognition of Subjective Meanings. Hermeneutic Analysis of Self-narration of People in Late Adulthood Using the Original Method of Content Interpretation}

\begin{abstract}
Phenomenological-existential psychology assumes that the human identity consists of the subjectively experienced meanings, inscribed in the system of meanings and senses present in the world in which he or she lives. Human can define and recognize his/her world of subjective meanings through narration and dialogue, and the form of self-narration reflects the shape of his/her identity (Ricoeur, 1992; McAdams, 1993; Riessman, 2008; Gergen, Gergen, 2011). Analysis and interpretation of the story in terms of these meanings, which are manifestations of human subjectivity, seems to be the most effective when undertaken in the hermeneutic approach. The article indicates the advantages of this method, illustrating its effectiveness in relation to the analysis and interpretation of the stories of people in the senior age about life-important experiences. Self-narratives were obtained through a modified version of the autobiographical-narrative interview according to the German sociologist Fritz Schütze (2007; Kaźmierska, Schütze, 2013). Content interpretation has been verified by its evaluation by the subjects. The presented analysis of two out of ten self-narratives obtained allowed to discover the subjective world of meanings of the subjects, deepen the knowledge about the subjective nature of human life, as well as verify the effectiveness of the applied method.
\end{abstract}

Keywords: self-narrative, subjective meanings, autobiographical experience, hermeneutic interpretation, late adulthood

Słowa kluczowe: autonarracja, subiektywne znaczenia, doświadczenie autobiograficzne, interpretacja hermeneutyczna, późna dorosłość 


\section{WPROWADZENIE}

Przedmiot niniejszego artykułu, reprezentującego interpretacyjne (rozumiejące) podejście do problemów psychologicznych, jest dwojaki.

Po pierwsze, jest nim ukazanie wybranych aspektów ludzkiej podmiotowości poprzez wgląd w podmiotowe znaczenia i sensy osób w wieku senioralnym. Wiek ten, jako wiek mądrościowy, charakteryzujący się perspektywą transcendentalną i osiągnięciem wyrazistej indywidualności, umożliwia zgłębianie istoty podmiotowości w jej dojrzałych, subtelnych i różnorodnych przejawach.

Po drugie, przedmiotem tym jest ukazanie naukowych korzyści (zwłaszcza dla badań z psychologii rozwoju człowieka w biegu życia), płynących z zastosowania oryginalnej metody analizy i interpretacji treści autonarracji, opartej na założeniach psychologii hermeneutycznej. W prezentowanych niżej badaniach została zweryfikowana skuteczność owej metody.

\section{Uchwycić ,ja podmiotowe" w narracji}

Psychologia fenomenologiczno-egzystencjalna przyjmuje, że tożsamość człowieka składa się z subiektywnie przeżywanych przez niego znaczeń, wpisanych w system znaczeń i sensów obecnych w świecie, w którym żyje. Poprzez narrację i dialog człowiek może określić i rozpoznać siebie, własny system ukrytych znaczeń, a forma autonarracji odzwierciedla kształt jego tożsamości (Ricoeur, 1992; McAdams, 1993; Dryll, 2004; 2013; Riessman, 2008; Gergen, Gergen, 2011; Cierpka, 2013).

Znaczenia osobiste - jak zauważa Maria Straś-Romanowska (2010) - są pochodną zarówno warunków życia, jak i interpretacji oraz efektem dynamicznych procesów kreacji, wyobraźni i myślenia. Mają charakter historyczny, temporalny, kontekstualny i relacyjny. Badanie relacji znaczeniowych jest jednym z ważniejszych zadań badaczy jakościowych. Fakt, iż metody jakościowe nie koncentrują się na weryfikacji hipotez, lecz opierają na swobodnej komunikacji i nieskrępowanej wypowiedzi osoby badanej, czyni możliwym ujawnienie jej osobistych znaczeń i sensów oraz uzyskanie holistycznego obrazu jej świata psychicznego.

Za Straś-Romanowską (1992, 2016) przyjmujemy (w duchu antropologii filozoficznej), że podmiot charakteryzuje się refleksyjną świadomością, otwartością poznawczą, wrażliwością aksjologiczną, wolną wolą i transgresyjnością. Przymioty te stanowią narzędzie jego egzystencjalnej wolności ${ }^{1}$, dzięki której może on przezwyciężać wewnętrzne i zewnętrzne ograniczenia, przymusy, kształtować własne życie, dokonywać wyboru wartości i samookreślać własne istnienie. Podmiot aktywnie analizuje to, co go spotyka, wątpi, rozważa dylematy i poszukuje sensu w wydarzeniach zewnętrznych i we własnym życiu. Otwartość poznawcza umożliwia mu przekraczanie granic obecnych w jego rzeczywistości i poszukiwanie nowych rozwiązań i sensów. Jak podkreśla Straś-Romanowska (2004), człowiek jako świadomy, refleksyjny, dokonujący wolnych wyborów podmiot jest bytem niepowtarzalnym, którego nie da się ująć w sieć przewidywalnych schematów psychologicznych metod ilościowych.

Z powyższym rozumieniem podmiotowości wiąże się podział na ,ja podmiotowe" i ,ja przedmiotowe" (Pervin, John, 1997), historycznie wywodzący się od Williama Jamesa (1892/2002). ,Ja przedmiotowe” pełni ważne funkcje w regulacji zachowania dzięki zjawiskom takim jak samoświadomość, samowiedza i struktura ja. „Ja podmiotowe” łączy się z właściwością specyficznie ludzką, jaką jest zdolność kierowania sobą i myślenia o sobie. Określane jest jako „centrum aktywności człowieka” (Straś-Romanowska, 2004). „Ja podmiotowe" związane jest $\mathrm{z}$ egzystencją, $\mathrm{tj}$. istnieniem człowieka w świecie; podmiotu, który pozostaje w ciągłej relacji ze światem, z sobą samym (ustosunkowuje się do samego siebie) i z innymi bytami, który odnosi się do wartości, a w wypadku człowieka wierzącego pozostaje w relacji z Bogiem. Docieranie do ,ja podmiotowego" - jak stwierdza Zenon Uchnast (1983) - możliwe jest wyłącznie poprzez spotkanie z drugim czlowiekiem i dialog, ja-ty".

W świetle powyższego, tożsamość narracyjna może powstać tylko dzięki specyficznie ludzkiej zdolności, jaką jest posługiwanie się 
językiem. Subiektywne znaczenia podmiotu wpisują się bowiem w jego narrację, a ujawniają w dialogu. Gdy przedmiotem badania czyni się właśnie ów świat wewnętrzny znaczeń i sensów człowieka widzianego w sposób podmiotowy, znajduje swoje uzasadnienie zastosowanie modelu rozumiejącego, czyli sięgnięcie do hermeneutycznej analizy ludzkiej wypowiedzi.

\section{Interpretacja hermeneutyczna wypowiedzi}

U podstaw hermeneutyki leży założenie o podmiotowości człowieka i o wolnej myśli ludzkiej, która przejawia się zarówno w faktach jednostkowego życia, jak i w dziełach kultury (Dilthey, 1982; Kwiatkowska, 1996; Markowska, 2007). Celem analizy hermeneutycznej jest dotarcie do ukrytych znaczeń tkwiących u podstaw tekstu poddawanego interpretacji. W ujęciu hermeneutycznym znaczenie przejawia się $\mathbf{w}$ dia$\operatorname{logu}$ - jest zawsze adresowane przez podmiot (autora tekstu) do odbiorcy oraz posiada dwa aspekty: subiektywny i obiektywny. Aspekt subiektywny znaczenia zawiera wewnętrzne, niekomunikowalne doświadczenie podmiotu. Jego ekspresja, dostępna odbiorcy, nosi nazwę znaczenia obiektywnego. Prawdziwe doświadczenie podmiotu jest nieprzekazywalne, gdyż między jego świadomością a świadomością odbiorcy wypowiedzi leży nieprzekraczalna bariera, ale sens tego doświadczenia, który podmiot pragnie przekazać, leży między subiektywnym i obiektywnym jego znaczeniem. Zadaniem odbiorcy jest odkrywanie znaczeń podmiotu, czyli docieranie do sensu jego osobistych doświadczeń poprzez interpretacyjne zgłębienie komunikowanego znaczenia obiektywnego. Kolejnym celem hermeneutycznej interpretacji jest dotarcie do wewnętrznej logiki wypowiedzi, wskazującej na głębiej ukryte znaczenia komunikowane przez podmiot $\mathrm{i}$ jest kluczem, według którego objaśnia on własne życie.

Życie psychiczne pozostaje w nierozerwalnym związku z wydarzeniami świata zewnętrznego otaczającego podmiot. Fakt ten uwzględnia w swojej teorii fenomenolog austriacki Ludwig Landgrebe (1968). W tym ujęciu przedmiotem rozumienia podmiotu jest zawarte w jego doświadczeniu ,położenie” - wewnętrzne odnie- sienie do otaczającego świata. Wyznaczają je trzy elementy: (1) całość zjawisk, osób i przedmiotów obecnych w życiu podmiotu, (2) spotykające go wydarzenia, a także (3) jego wolne wybory i decyzje.

Główna metoda hermeneutycznego rozumienia, tzw. koło hermeneutyczne, opiera się na rozpoznawaniu związków sensu między poszczególnymi elementami wypowiedzi, a także między każdym z nich a całością (Dilthey, 1982; Markowska, 2007). Punktem wyjścia interpretacji jest tu początkowa intuicyjna próba zrozumienia tekstu jako całości, do której następnie odnosi się interpretację poszczególnych jego części. Lepsze zrozumienie części umożliwia z kolei głębsze zrozumienie całości. Metoda ta umożliwia stopniowe pogłębianie rozumienia sensów zawartych w wypowiedzi, które trwa aż do momentu uzyskania ,dobrej postaci” interpretacji, to znaczy wolnej od wewnętrznych sprzeczności. Warunkami niezbędnymi do osiągnięcia rozumienia są brak wstępnych założeń wprowadzanych do interpretacji, a także postawa gotowości i otwartości interpretującego (Radnitzky, 1970).

W autonarracji realizuje się podmiotowość człowieka, który poddaje refleksji własne życie i nadaje mu sens. „Ja podmiotowe” odgrywa tu rolę autora narracji, a ,ja przedmiotowe" rolę jej bohatera. W ten sposób poprzez autonarrację człowiek przeżywa własne życie, a zarazem ocenia je, komentuje $\mathrm{i}$ interpretuje (Hermans, Hermans-Jansen, 2000; Trzebiński, 2002; Cierpka, 2013).

Doświadczenie jest przechowywane w pamięci autobiograficznej. Funkcją pamięci jest kodowanie go ze względu na jego subiektywne znaczenie. Doświadczenia ważne dla ,ja” są pamiętane lepiej i szybciej przywoływane z pamięci, dlatego sama dostępność pamięciowa doświadczenia wskazuje na jego wagę i znaczenie (Maruszewski, 2011). Rekonstrukcja systemu znaczeń podmiotowych zawartych w autonarracji wymaga rozpoznania ważnych dla osoby doświadczeń, myśli i przeżyć.

Interpretacja hermeneutyczna wychodzi od próby całościowego i ogólnego rozumienia tekstu. Etap ten nazywany jest przedrozumieniem. Ze względu na główną w nim rolę intuicji 
przedrozumienie może opierać się na przyporządkowaniu do tekstu metafor oddających jego holistyczny i kontekstualny charakter (Frye, 1963; Elsbree, 1982). Przedrozumienie może także zawierać próbę odpowiedzi na pytania dotyczące narracji, roli i perspektywy narratora i uczestnika wydarzeń.

Kolejny etap interpretacji ma na celu odszukanie sensów cząstkowych zawartych w narracji. W wypadku referowanych badań wykorzystano na tym etapie analizę tekstu od strony formalnej oraz analizę powiązań między wymienionymi w opowieści doświadczeniami a przeżyciami osoby.

Analiza formalna opiera się na założeniu, iż struktura językowa narracji stanowi odbicie jej struktury znaczeniowej. Jednostką wyróżnianą na tym poziomie analizy jest temat, który odnosi się do poszczególnych wymiarów życia osoby badanej. Ustalenie struktury narracji wymaga określenia częstości pojawiania się danych tematów, czasu poświęconego im w opowieści, a także związków między tematami. Umożliwia to nadanie wypowiedzi pewnej przejrzystości i wyłonienie pierwszego szkicu subiektywnych znaczeń. Następny etap interpretacji skupia się na konkretnych doświadczeniach autobiograficznych przywołanych przez narratora. Analiza pojęć użytych w opisie doświadczenia służy odkryciu przeżyć, jakie łączą się z danym doświadczeniem. Te przeżycia i emocje, a także komentarze, którymi badany opatruje to doświadczenie, wskazują na jego subiektywną ważność i sens.

Znaczenia łączące się z konkretnymi doświadczeniami potwierdzają lub osłabiają wyniki uzyskane w analizie formalnej. Na bazie syntezy obu tych etapów można wnioskować o ogólnym systemie znaczeń podmiotowych.

\section{PROBLEMATYKA BADAŃ}

Aby podmiot ujawnił w narracji istotne dla niego znaczenia, musi w nim powstać odpowiednia ku temu motywacja. O motywacji tej decyduje zarówno kształt relacji z odbiorcą, jak i temat narracji. Rolą tematu jest zorganizowanie wątku narracji, dzięki któremu nie przedstawia ona jedynie chronologicznego układu zdarzeń, ale ujawnia istotne dla podmiotu znaczenia (Hermans, Hermans-Jansen, 2000). Do celów prezentowanych badań opracowano metodę przeprowadzenia wywiadu pod kątem jej skuteczności w zakresie motywowania podmiotu do ujawniania osobistych znaczeń.

Uchwycenie struktur znaczeniowych podmiotu wymaga odrzucenia własnej perspektywy przez interpretującego i spojrzenia na doświadczenia osoby badanej z jej punktu widzenia (Denzin, 1990; Kwiatkowska, 1996; Straś-Romanowska, 1997). W prezentowanych badaniach podjęto próbę spełnienia tego warunku.

Celem głównym badań było uzyskanie wglądu w subiektywny świat znaczeń osób w wieku senioralnym (jako przejawu ludzkiej podmiotowości), komunikowanych w narracji autobiograficznej (bez generalizacji wyników i odnoszenia ich do ogólnie obowiązujących zasad psychologicznych). Jednocześnie weryfikowano skuteczność autorskiej metody analizy i interpretacji tekstu. Szukano odpowiedzi na pytanie, czy umożliwia ona dotarcie do autentycznego świata znaczeń podmiotu oraz interpretację tych znaczeń zgodną ze sposobem ich rozumienia przez podmiot narracji. Jako kryterium wiarygodności (rzetelności) tej metody potraktowano odniesienie wyników do opinii osoby badanej. W autonarracji podmiot przekazuje sens swojego wewnętrznego, niekomunikowalnego doświadczenia. Tak więc to on sam jest ekspertem co do własnego systemu znaczeń i może potwierdzić lub odrzucić wyniki interpretacji.

\section{METODA}

\section{Schemat badania}

Badania miały charakter indywidualny. Składały się z trzech etapów. Pierwszym było przeprowadzenie wywiadu autobiograficzno-narracyjnego, którego treść poddano transkrypcji. Etapem drugim była interpretacja przez badacza zebranego materiału. Etap trzeci służył weryfikacji poprawności interpretacji, czyli jej uwiarygodnieniu. Wtedy to wyniki analizy skonfrontowano z opinią osoby badanej. 


\section{Wywiad autobiograficzno-narracyjny}

\section{Sposób przeprowadzenia wywiadu}

Autonarrację uzyskano za pomocą zmodyfikowanej autorsko wersji wywiadu autobiograficzno-narracyjnego według socjologa niemieckiego Fritza Schütze (1976, za: Helling, 1990; Schütze, 2007; Kaźmierska, Schütze, 2013).

Zgodnie z założeniami teoretyczno-metodologicznymi podstawową zaletą wywiadu autobiograficzno-narracyjnego jest możliwość odtworzenia przez narratora (1) doświadczanych przez niego znaczących procesów biograficznych, które kształtowały jego życie w kolejnych fazach biografii, (2) doświadczonych sytuacji oraz (3) ram społecznych, w których przebiegały jego procesy biograficzne (Kaźmierska, Schütze, 2013). Technika ta opiera się na przekonaniu, że skłonienie osoby badanej do ujawniania osobistych znaczeń powinno mieć za punkt wyjścia pytanie o charakterze otwartym - tzw. bodziec narracyjny, na który udziela ona swobodnej odpowiedzi.

Zastosowany wywiad składał się z dwóch etapów:

Po pierwsze: osobie badanej odczytywano wydrukowaną na kartce treść następującego bodźca narracyjnego:

W życiu spotyka nas wiele doświadczeń, czasem trudnych, a czasem bardzo pięknych. Niektóre z nich pozostaja $w$ naszej pamięci na dhugo i sa dla nas czymś ogromnie cennym. Chciatam Pana/Pania prosić, by opowiedzial(a) mi Pan/ Pani o takich waznych dla Pana/Pani doświadczeniach, bym dzięki Pana/Pani opowieści mogła dowiedzieć się czegoś więcej o życiu, a zwłaszcza o tym, co jest w nim tak naprawdę ważne.

Po zapoznaniu osoby badanej z bodźcem narracyjnym, proszono ją o przemyślenie jego treści. Odpowiedzi udzielała na następnym spotkaniu, kilka dni później. Wydrukowaną treść bodźca narracyjnego pozostawiano w jej domu.

Po drugie: podczas kolejnego spotkania badacz odczytywał powtórnie bodziec narracyjny. Następnie osoba badana tworzyła swobodną autonarrację. Kończyła ją, gdy sama uznała, że wyczerpała temat.

\section{Sposób interpretacji wywiadu}

Przyjęta metoda interpretacji składała się z następujących etapów:
A) przedrozumienie,
B) analiza formalna,
C) analiza powiązań między doświadcze- niami a przeżyciami i refleksjami pod- miotu,
D) synteza etapu B i C,
E) synteza etapu D i A.

Ad A) Celem tego etapu była całościowa, intuicyjna próba zrozumienia tekstu. Środkiem do tego celu było poszukiwanie odpowiedzi na pytania:

- Jaka jest rola i perspektywa narratora oraz bohatera narracji?

- Jaka jest struktura narracji?

Ad B) Celem analizy formalnej była próba określenia struktury narracji, zgodnie z przyjętą zasadą, iż struktura formalna stanowi odbicie struktury znaczeniowej. Na tym etapie poddano analizie częstość występowania poszczególnych tematów i czas poświęcony im w opowieści.

Wstępnie posłużono się kategoriami kontekstów ludzkiego doświadczenia użytymi w badaniach Bogny Bartosz (2004), do których dołączono dodatkowe kategorie wynikające $\mathrm{z}$ interpretowanych narracji. Przyjęto podział na siedem kontekstów ludzkiego doświadczenia: osobowy, moralny, egzystencjalny, społeczny, emocjonalny, związany ze zdobywaniem wiedzy i związany $z$ dzialaniem. W ramach każdego z kontekstów wyodrębniono konkretne tematy. Doświadczenia przywołane przez osobę badaną przypisano, na podstawie użytych przez nią wyrażeń i sformułowań, do tychże tematów. Zanalizowano czas poświęcony im w opowieści. Określono udział czasowy poszczególnych tematów w całości narracji. Podsumowano wyniki tego etapu interpretacji, wskazując na tematy o największym subiektywnym znaczeniu najczęściej poruszane i najdłużej omawiane.

Ad C) W tej części analizy skupiono się jedynie na uogólnionych doświadczeniach osoby badanej. Poszukiwano w narracji wypowiedzi świadczących, iż z danym doświadczeniem łączyło się przeżycie emocjonalne lub odnosiła się do tego doświadczenia pewna refleksja. Wyłoniono zdania najbardziej istotne w kontekście 
każdego z doświadczeń. Na podstawie wybranych zdań wnioskowano o łączących się z danym doświadczeniem uczuciach. Rozpoznanie konkretnego uczucia wskazywało zarazem na kontekst, w jakim owo doświadczenie odcisnęło swoje znaczenie. Na podstawie rozpoznanych uczuć i kontekstów, a także refleksji osoby badanej wnioskowano o znaczeniach łączących się z poszczególnymi doświadczeniami

Ad D) Przypisane do doświadczeń znaczenia odniesiono do uzyskanych w etapie analizy formalnej wyników dotyczących znaczeń przypisywanych tematom. $\mathrm{Na}$ ich podstawie dokonano zmian w naszkicowanym schemacie podmiotowych znaczeń, a także przybliżono i pogłębiono ich treść.

Ad E) Porównano uzyskany schemat znaczeń z wynikami otrzymanymi w przedrozumieniu. Wnioskowano o możliwych powiązaniach i zależnościach między wynikami tych etapów. W sytuacji, gdy wyniki etapu A, B i C były wewnętrznie spójne, analizę uznano za zakończoną.

\section{Proces uwiarygodniania interpretacji}

Określone w procesie interpretacji znaczenia podmiotowe sformułowano w postaci zdań wypowiadanych w pierwszej osobie. Oprócz autorek w pracę tę zostali włączeni dwaj sędziowie kompetentni - psychologowie odpowiednio przeszkoleni, zaznajomieni z badaniami. Do każdego ze zdań przypisano pięciostopniową skalę ( 1 - całkowicie się nie zgadzam, 2 - nie zgadzam się, 3 - trudno powiedzieć, 4 - zgadzam się, 5 - całkowicie się zgadzam). Zdania te utworzyły ankietę, którą prezentowano osobie badanej (zał. 1 i 2). Liczbę punktów przez nią zaznaczonych sumowano i dzielono przez najwyższy możliwy wynik, a następnie mnożono przez sto procent. W ten sposób uzyskano wskaźnik stopnia zgodności interpretacji z opinią osoby badanej oznaczony symbolem SZI.

Spodziewano się, że jeżeli przyjęta metoda interpretacji uniknie błędu subiektywizmu i doprowadzi do rozpoznania komunikowanych przez osobę badaną znaczeń, wówczas stopień zgodności interpretacji z jej opinią wyniesie nie mniej niż 60\% (co odpowiada zgodności dobrej lub bardzo dobrej - zob. Krejtz, Krejtz, 2013b; Gorbaniuk, 2016).

\section{Osoby badane i procedura}

W badaniach wzięło udział dziesięć osób po 70 . roku życia, obu płci. Średnia wieku wynosiła 71 lat. Wszyscy byli mieszkańcami Warszawy. Siedem osób posiadało wykształcenie wyższe, a trzy średnie. Zdecydowałyśmy się przedstawić $\mathrm{w}$ artykule analizę autonarracji dwóch z tych osób, by móc ukazać szczegółowo wyniki zastosowanej metody interpretacji treści. Przy uwzględnieniu większej liczby osób badanych nie byłoby to możliwe ${ }^{2}$.

Osoby, których wyniki badania są niżej prezentowane, wybrano losowo. Były to:

- Pani I. - wdowa, lat 72, przebywająca w domu pomocy społecznej,

- Pani J. - wdowa, lat 71, mieszkająca samotnie.

Każdy z etapów badania odbywał się indywidualnie $\mathrm{w}$ miejscu zamieszkania osoby badanej, w warunkach sprzyjających dialogowi ${ }^{3}$.

\section{WYNIKI}

\section{Interpretacja opowieści Pani I.}

\section{A) Przedrozumienie}

- Narrator toczy swoją opowieść, tłumaczy szczegóły zachodzących wydarzeń i w dość małym stopniu odnosi się do uczuć bohatera. Mówi o sobie i o swoich doświadczeniach momentami żartobliwie, momentami z dużym przejęciem i naciskiem. Ten nacisk pojawia się szczególnie, kiedy narrator opowiada o wydarzeniach budzących w nim opór i sprzeciw. Kilkakrotnie narrator zwraca się wprost do słuchacza opowieści.

- Bohater opowieści często wysuwa się na pierwszy plan, czasem jednak zdaje się niknąć wśród opisu różnych wydarzeń i okoliczności. Bardzo mało jest w opowieści opisów relacji bohatera z innymi postaciami. To on odgrywa główną rolę. Od początku zdaje się bardzo samodzielny.

- Opowieść rozpoczyna się i kończy opisem pobytu w domu pomocy społecznej. Toczy się w porządku chronologicznym. Przeplatają się w niej motywy opisu dziejących się, niezależnych od bohatera wydarzeń z opowieściami jego działań. 


\section{B) Analiza formalna}

Narracja Pani I. trwała 183 minuty. Tabela 1 przedstawia sposób, w jaki przypisano doświadczenia przywołane w opowieści Pani I. do poszczególnych tematów, czas im poświęcony oraz wskaźnik procentowy udziału czasowego tematu w całej narracji (UT), obliczany według wzoru:

$$
\mathrm{UT}=\frac{\mathrm{CZ}_{\mathrm{t}}}{\mathrm{CZ}_{\mathrm{n}}} \times 100 \%
$$

gdzie: $\mathrm{CZ}_{\mathrm{t}}$ - czas poświęcony tematowi; $\mathrm{CZ}_{\mathrm{n}}$ - czas poświęcony całej narracji.

Tabela 1. Kontekst doświadczeń i ich tematy w opowieści Pani I., wydarzenia im przypisane, czas im poświęcony $\left(\mathrm{CZ}_{\mathrm{t}}\right)$ oraz wskaźnik procentowy udziału tematu w narracji (UT)

\begin{tabular}{|c|c|c|c|c|}
\hline $\begin{array}{c}\text { Kontekst } \\
\text { doświadczeń }\end{array}$ & \begin{tabular}{c|} 
Temat \\
doświadczeń
\end{tabular} & Wydarzenie & $\begin{array}{c}\mathrm{CZ}_{\mathrm{t}} \\
\text { (minuty) }\end{array}$ & $\begin{array}{l}\text { UT } \\
(\%)\end{array}$ \\
\hline \multirow{20}{*}{ osobowy } & strata & 1. Choroba i śmierć męża & 5 & 2.73 \\
\hline & \multirow{4}{*}{ porażka } & 1. Doświadczenie wojny i okupacji & 6 & \multirow{4}{*}{6.01} \\
\hline & & 2. Nauka gry na skrzypcach & 3 & \\
\hline & & 3. Choroba - ostre zapalenie stawów & 1 & \\
\hline & & 4. Nauka w liceum ogólnokształcącym & 1 & \\
\hline & \multirow{5}{*}{ sukces } & 1. Zdobycie węgla od Niemców & 2 & \multirow{5}{*}{4.37} \\
\hline & & 2. Ukończenie technikum ekonomicznego & 1 & \\
\hline & & 3. Praca w ZUS-ie & 1 & \\
\hline & & 4. Nauka w technikum plastycznym & 2 & \\
\hline & & 5. Awans na kierownika klubu profesorskiego & 1 & \\
\hline & \multirow{6}{*}{$\begin{array}{l}\text { walka o sie- } \\
\text { bie i swoje } \\
\text { przekonania }\end{array}$} & 1. Obrona ojca przed Niemcem & 1 & \multirow{6}{*}{7.65} \\
\hline & & 2. Zdobycie węgla od Niemców & 2 & \\
\hline & & 3. Sprzeciw wobec dyrektora w fabryce FSO & 3 & \\
\hline & & 4. Pochowanie męża zgodne $\mathrm{z}$ jego wolą & 2 & \\
\hline & & 5. Samodzielność mimo choroby & 1 & \\
\hline & & $\begin{array}{l}\text { 6. Pismo do urzędu w sprawie nieuczciwego po- } \\
\text { traktowania przez dyrektora DPS-u }\end{array}$ & 5 & \\
\hline & \multirow{4}{*}{$\begin{array}{l}\text { rozwój } \\
\text { osobowy }\end{array}$} & 1. Dzieciństwo spędzone w domu rodzinnym & 5 & \multirow{4}{*}{5.46} \\
\hline & & 2. Nabycie sprytu podczas wojny & 2 & \\
\hline & & 3. Nauka w technikum plastycznym & 2 & \\
\hline & & 4. Podjęcie studiów & 1 & \\
\hline \multirow{6}{*}{ moralny } & \multirow{6}{*}{\begin{tabular}{|l|} 
doświadcze- \\
nie niespra- \\
wiedliwości/ \\
nieuczciwo- \\
ści ludzkiej
\end{tabular}} & 1. Doświadczenie wojny i okupacji & 2 & \multirow{6}{*}{15.30} \\
\hline & & 2. Przymuszenie do pracy przez Niemców & 2 & \\
\hline & & $\begin{array}{l}\text { 3. Niesprawiedliwe potraktowanie ojca przez } \\
\text { Niemca }\end{array}$ & 3 & \\
\hline & & 4. Spotkanie księdza Maja & 3 & \\
\hline & & 5. Żądania córki męża z poprzedniego małżeństwa & 3 & \\
\hline & & 6. Funkcjonowanie DPS-u & 15 & \\
\hline
\end{tabular}




\begin{tabular}{|c|c|c|c|c|}
\hline $\begin{array}{c}\text { Kontekst } \\
\text { doświadczeń }\end{array}$ & $\begin{array}{c}\text { Temat } \\
\text { doświadczeń }\end{array}$ & Wydarzenie & $\begin{array}{c}\mathrm{CZ}_{\mathrm{t}} \\
\text { (minuty) }\end{array}$ & $\begin{array}{l}\text { UT } \\
\text { (\%) }\end{array}$ \\
\hline \multirow{8}{*}{$\begin{array}{l}\text { egzystencjal- } \\
\text { ny }\end{array}$} & \multirow{2}{*}{ śmierć } & 1. Choroba i śmierć męża & 5 & \multirow{2}{*}{3.28} \\
\hline & & 2. Śmierć i choroba rodzeństwa & 1 & \\
\hline & \multirow{3}{*}{ choroba } & 1. Pobyt w DPS-ie & 1 & \multirow{3}{*}{2.19} \\
\hline & & 2. Choroba - ostre zapalenie stawów & 1 & \\
\hline & & 3. Udar i jego konsekwencje & 2 & \\
\hline & \multirow{2}{*}{$\begin{array}{l}\text { nieprzyjazne } \\
\text { warunki } \\
\text { egzystencji }\end{array}$} & 1. Doświadczenie wojny i okupacji & 11 & \multirow{2}{*}{14.21} \\
\hline & & 2. Życie w DPS-ie & 15 & \\
\hline & $\begin{array}{l}\text { przyjazne } \\
\text { warunki } \\
\text { egzystencji }\end{array}$ & 1. Dzieciństwo spędzone w domu rodzinnym & 5 & 2.73 \\
\hline \multirow{6}{*}{ społeczny } & \multirow{3}{*}{$\begin{array}{l}\text { relacje } \\
\text { z rodziną }\end{array}$} & 1. Dzieciństwo spędzone w domu rodzinnym & 5 & \multirow{3}{*}{3.83} \\
\hline & & 2. Opieka nad chorym bratem & 1 & \\
\hline & & 3. Choroba i śmierć rodzeństwa & 1 & \\
\hline & \multirow{3}{*}{$\begin{array}{l}\text { poznawanie } \\
\text { ludzi/praca } \\
\text { z ludźmi }\end{array}$} & 1. Praca w FSO & 5 & \multirow{3}{*}{6.56} \\
\hline & & 2. Praca jako pracownik socjalny w SGPiS-ie & 2 & \\
\hline & & 3. Praca jako kierownik klubu profesorskiego & 5 & \\
\hline \multirow{7}{*}{ emocjonalny } & \multirow{4}{*}{ miłość } & 1. Dzieciństwo spędzone w domu rodzinnym & 5 & \multirow{4}{*}{6.56} \\
\hline & & 2. Poznanie przyszłego męża & 1 & \\
\hline & & 3.Wsparcie i rada męża dotycząca studiów & 1 & \\
\hline & & 4. Choroba i śmierć męża & 5 & \\
\hline & przyjaźń & 1. Pomoc przyjaciół po śmierci męża & 1 & 0.55 \\
\hline & \multirow{2}{*}{$\begin{array}{l}\text { uczucia nie } \\
\text { dotyczące } \\
\text { ludzi }\end{array}$} & 1. Miłość do przyrody & 2 & \multirow{2}{*}{2.19} \\
\hline & & 2. Opieka nad białą koteczką & 2 & \\
\hline \multirow{4}{*}{$\begin{array}{l}\text { związany ze } \\
\text { zdobywa- } \\
\text { niem wiedzy }\end{array}$} & \multirow{4}{*}{$\begin{array}{l}\text { szkoła/ } \\
\text { uczelnia }\end{array}$} & 1. Zadawanie pytań rodzicom & 3 & \multirow{4}{*}{7.10} \\
\hline & & 2. Nauka w czasie wojny & 2 & \\
\hline & & 3. Nauka w liceum i technikum & 6 & \\
\hline & & 4. Studia resocjalizacyjne & 2 & \\
\hline \multirow{7}{*}{$\begin{array}{l}\text { związany } \\
\text { z działaniem }\end{array}$} & \multirow{5}{*}{$\begin{array}{l}\text { praca } \\
\text { zawodowa }\end{array}$} & 1. Praca w ZUS-ie & 1 & \multirow{5}{*}{7.65} \\
\hline & & 2. Praca w FSO & 5 & \\
\hline & & 3. Praca jako pracownik socjalny w SGPiS-ie & 2 & \\
\hline & & 4. Praca jako kierownik klubu profesorskiego & 5 & \\
\hline & & 5. Praca w radzie osiedlowej & 1 & \\
\hline & \multirow{2}{*}{$\begin{array}{l}\text { zaintereso- } \\
\text { wania/pasje }\end{array}$} & 1. Nauka w technikum plastycznym & 2 & \multirow{2}{*}{1.64} \\
\hline & & 2. Szycie ubiorów & 1 & \\
\hline
\end{tabular}

Pani I. poświęciła najwięcej czasu w opowieści doświadczeniom niesprawiedliwości i nieuczciwości, a także nieprzyjaznym warunkom życia. Może się to łączyć z faktem, iż są to znaczenia najbardziej obecne w jej teraźniejszości. Liczba doświadczeń odnoszących się do tematu „doświadczenie niesprawiedliwości” wskazuje, iż Pani I. jest szczególnie wrażliwa na ten wymiar swojego doświadczenia. Duże znaczenie przykłada ona do tematów takich, jak praca zawodowa, obrona siebie i własnych przekonań, nauka, rozwój osobowy, poznawanie ludzi i praca $z$ nimi. Przejawia aktywną postawę wobec świata. W jej doświadczeniu są 
sukcesy i porażki, tak więc odnajduje pewien sens zarówno w ciemnych, jak i jasnych jego stronach. Istotne znaczenie ma dla niej także miłość do osób bliskich.
C) Analiza powiazań między doświadczeniami a przė̇yciami i refleksjami podmiotu

W tabeli 2 przedstawiono metodą ilustracji najbardziej istotne wypowiedzi Pani I. odnoszące się do poszczególnych doświadczeń.

Tabela 2. Wypowiedzi Pani I. ważne w kontekście poszczególnych doświadczeń

\begin{tabular}{|c|c|}
\hline Doświadczenie & Wypowiedzi \\
\hline 1. Dzieciństwo & $\begin{array}{l}\text { „W tamtym okresie była dla mnie ważna radość życia”. „Nie myślałam o tym, } \\
\text { co jest najgorsze w życiu, ale o tym, co jest ważne w życiu”. „Wytłumaczono mi, że } \\
\text { życiem człowieka jest rodzina, która powinna trzymać się razem [...], że zadaniem rodzi- } \\
\text { ców jest wychowanie dzieci na zdrowych, pogodnych, kochających się”. }\end{array}$ \\
\hline 2. Okres wojny & $\begin{array}{l}\text { „Doznawałam różnych, bardzo nieprzyjemnych, przerażających mnie momentów”. } \\
\text { „W brutalne prace angażowano zarówno dorosłych, jak i dzieci. Nie liczono się absolut- } \\
\text { nie z ich potrzebami”., ,Widząc, jak Niemiec bije mojego ojca, chwyciłam kamień i ude- } \\
\text { rzyłam”. „Umiałam nabyć jakiegoś sprytu”. }\end{array}$ \\
\hline 3. Nauka & $\begin{array}{l}\text { „Pokochałam język niemiecki i chciałam wiedzieć więcej”. „Uczyłam się pisania i chło- } \\
\text { nęłam to z wielkim zapałem”. „Wymagało to skupienia i zdolności, ale moja wzroko- } \\
\text { wość ogarniała to”. }\end{array}$ \\
\hline $\begin{array}{l}\text { 4. Praca zawodo- } \\
\text { wa, praca z ludźmi }\end{array}$ & $\begin{array}{l}\text { „Ja zawsze podchodziłam tak serio do spraw”. „Ludzie pisali i narzekali [...], } \\
\text { to wszystko się we mnie kumulowało, kumulowało...”. „Ale to wszystko przeżyłam } \\
\text { i niczego nie żałuję, ponieważ przywiązuję wagę do życia na bieżąco, do komunikatywy } \\
\text { z ludźmi, do pomagania ludziom, ponieważ w tym duchu byłam wychowana”. }\end{array}$ \\
\hline $\begin{array}{l}\text { 5. Relacje } \\
\text { z mężem }\end{array}$ & $\begin{array}{l}\text { „Mąż, doceniając mnie, bo ja zawsze doceniałam jego zdolności i jego umiejętności, [...] } \\
\text { namówił mnie, żebym zajęła się studiami”. „Doznałam klęski takiej rodzinnej, ponieważ } \\
\text { mój mąż miał kolejne zawały”. }\end{array}$ \\
\hline $\begin{array}{l}\text { 6. Choroba i pobyt } \\
\text { w DPS-ie }\end{array}$ & $\begin{array}{l}\text { „To, co jest dla mnie życiowym gorzkim doświadczeniem, to to, że muszę przebywać w tzw. } \\
\text { DPS-ie, ale nie sądzę, żeby nad tym ubolewać, bo jestem świadoma życia, prawda jest taka, } \\
\text { że «Kto się urodził, umrzeć musi [...]»”., ,Ja cały czas byłam taka samodzielna i nie chciałam } \\
\text { żadnej litości, i jak mnie ten udar dotknął, to też sobie poradziłam”. ,Nie zawsze znajduje się } \\
\text { tutaj radość życia [...], mimo to ja staram się tę samodzielność w sobie kształtować”. }\end{array}$ \\
\hline
\end{tabular}

W tabeli 3. ukazano efekty wnioskowania dotyczącego uczuć i znaczeń łączących się z poszczególnymi doświadczeniami w opowieści Pani I.

Tabela 3. Uczucia i znaczenia łączące się z doświadczeniami Pani I.

\begin{tabular}{|l|l|}
\hline Doświadczenie & \multicolumn{1}{c|}{ Uczucia i znaczenia } \\
\hline \multirow{3}{*}{ 1. Dzieciństwo } & $\begin{array}{l}\text { Uczucia: akceptacja, poznawanie świata i własnych możliwości, bezpieczeństwo, radość, } \\
\text { sens życia, więź, zaufanie }\end{array}$ \\
\cline { 2 - 3 } 2. Okres wojny & $\begin{array}{l}\text { Znaczenia: Doświadczenie dzieciństwa odcisnęło swoje znaczenie w kontekście osobo- } \\
\text { wym, emocjonalnym i egzystencjalnym Pani I. To doświadczenie jest dla niej ważne ze } \\
\text { względu na radość, jaką jej dostarczyło, oraz ze względu na wartości, których została } \\
\text { w tym okresie nauczona, takie jak wartość rodziny i miłość do przyrody. }\end{array}$ \\
\hline & $\begin{array}{l}\text { Uczucia: zagubienie, bezradność, wrażliwość, narzucenie, ograniczenie, ale też samo- } \\
\text { dzielność, siła wewnętrzna }\end{array}$ \\
\cline { 2 - 2 } & $\begin{array}{l}\text { Znaczenia: Doświadczenie wojny również wywarło wpływ na kontekst osobowy, } \\
\text { emocjonalny i egzystencjalny osoby badanej, a także na kontekst moralny. Znaczenie } \\
\text { tego doświadczenia jest takie, iż mimo trudnych i przerażających warunków życia nie } \\
\text { wpłynęło ono destrukcyjnie na psychikę osoby badanej, a wręcz przeciwnie - sprawiło, } \\
\text { iż znalazła w sobie siłę i odwagę. Kolejnym znaczeniem może być bunt przeciwko do- } \\
\text { świadczonemu złu i niesprawiedliwości. }\end{array}$ \\
\hline
\end{tabular}




\begin{tabular}{|c|c|}
\hline \multirow[b]{2}{*}{ 3. Nauka } & Uczucia: pewność siebie, przekonanie o własnych kompetencjach, aktywność, zapał \\
\hline & $\begin{array}{l}\text { Znaczenia: Doświadczenie nauki zawiera się w obszarze zarówno osobowym, jak i związa- } \\
\text { nym ze zdobywaniem wiedzy i z działaniem. Nauka jest dla osoby badanej ważna, gdyż umoż- } \\
\text { liwia budowanie pewności siebie, daje satysfakcję i poczucie lepszego rozumienia świata. }\end{array}$ \\
\hline \multirow[b]{2}{*}{$\begin{array}{l}\text { 4. Praca zawodo- } \\
\text { wa, praca z ludźmi }\end{array}$} & $\begin{array}{l}\text { Uczucia: pewność siebie, odwaga, przekonanie o własnych kompetencjach, bycie soba, } \\
\text { aktywność, siła wewnętrzna, ale też poczucie niezrozumienia i doświadczanie trudności }\end{array}$ \\
\hline & $\begin{array}{l}\text { Znaczenia: Doświadczenie pracy zawodowej wywarło wpływ na obszar społeczny, egzy- } \\
\text { stencjalny, związany z działaniem, a także moralny w życiu osoby badanej. Widać, iż jest } \\
\text { to doświadczenie szczególnie ważne w budowaniu jej tożsamości. Jak sama zaznacza, } \\
\text { jest ono zakorzenione w wartościach wyniesionych z dzieciństwa i mimo trudności na- } \\
\text { daje życiu sens. } Z \text { tym doświadczeniem wiąże się również bunt przeciw niemoralnemu } \\
\text { zachowaniu innych ludzi. }\end{array}$ \\
\hline \multirow{2}{*}{$\begin{array}{l}\text { 5. Relacje } \\
\text { z mężem }\end{array}$} & Uczucia: akceptacja, zrozumienie \\
\hline & $\begin{array}{l}\text { Znaczenia: Relacja z mężem była dla osoby badanej ważna, ponieważ dawała jej uczucie } \\
\text { wzajemnej akceptacji, wsparcia i szacunku. }\end{array}$ \\
\hline \multirow[b]{2}{*}{$\begin{array}{l}\text { 6. Pobyt } \\
\text { w DPS-ie }\end{array}$} & $\begin{array}{l}\text { Uczucia: ograniczenie, niezrozumienie, wrażliwość, bezradność, zagubienie, ale też ak- } \\
\text { ceptacja, samodzielność, odwaga, aktywnoś, sens życia }\end{array}$ \\
\hline & $\begin{array}{l}\text { Znaczenia: Pobyt w DPS-ie jest dla Pani I. trudny, ponieważ budzi w niej bunt doświad- } \\
\text { czana niesprawiedliwość i działania niezgodne z przyswojonymi przez nią wartościami. } \\
\text { Pozostaje im wierna i podejmuje aktywność, która umożliwia jej pozostanie sobą. Mimo } \\
\text { doświadczanych trudności akceptuje swoją sytuację. Walka o samodzielność jest dla niej } \\
\text { w tym okresie szczególnie ważna. }\end{array}$ \\
\hline
\end{tabular}

\section{D) Synteza etapu B i C}

Dzięki etapowi C zobaczono, iż dla Pani I. bardzo ważne było jej dzieciństwo, ponieważ zapewniło jej uczucie szczęścia i dostarczyło wiary w wartości. W etapie B dowiedziano się, iż Pani I. przykłada dużą wagę do doświadczenia niesprawiedliwości i nieuczciwości. Wyniki etapu C pokazały, iż wrażliwość na tego typu sytuacje łączy się u niej z wartościami, które przyswoiła $\mathrm{w}$ dzieciństwie i które stara się realizować w życiu. W takich sytuacjach bardzo ważna jest dla niej aktywność i czynne przeciwstawienie się niesprawiedliwości.

Na podstawie analizy formalnej dowiedziano się, iż w życiu Pani I. ważne były sytuacje, w których musiała walczyć o siebie i o swoje przekonania. Etap C pokazał, iż walka o siebie jest ważnym elementem jej czynnej postawy wobec świata i formą utrzymania tożsamości w sytuacjach trudnych. Oba etapy analizy wskazały na rolę, jaką w życiu Pani I. odegrała praca zawodowa i nauka.

W pracy ważny był dla niej kontakt z ludźmi, który mimo trudności umożliwiał jej życie w zgodzie $\mathrm{z}$ własnymi przekonaniami, a także dawał poczucie kompetencji i siły wewnętrznej. Była też osobą ciekawą świata, dlatego nauka i poznawanie nowych rzeczy były dla niej ważne same
W sobie. W etapie B dowiedziano się, że ważna była dla niej miłość do bliskich osób. Dzięki etapowi C zobaczono, iż miłość była dla niej ważna ze względu na wzajemne wsparcie i zrozumienie.

W etapie analizy formalnej bardzo widoczny był fakt, iż Pani I. przykłada dużą wagę do nieprzyjaznych warunków egzystencji. W etapie $\mathrm{C}$ zobaczono, iż łączy się to $\mathrm{z}$ doświadczeniem buntu i bezsilności wobec działania domu pomocy społecznej. Etap ten pokazał, iż mimo tych złych warunków życia osoba badana akceptuje rzeczywistość i nadal przykłada dużą wagę do samodzielności i kontaktów z ludźmi.

Pomiędzy etapami B i C brak jest widocznych niespójności logicznych.

\section{E) Synteza etapu D i A}

Opisana w przedrozumieniu postawa narratora, który w małym stopniu odnosi się do uczuć, zgadza się z aktywną postawą Pani I., która przykłada dość dużą wagę do działania. Nacisk pojawiający się w momentach, w których Pani I. wypowiada się o wydarzeniach według niej niesprawiedliwych, potwierdza, iż jest to temat o dużym dla niej znaczeniu. Już w przedrozumieniu zauważono, iż bohater opowieści jest bardzo samodzielny. Etap D wskazuje, że Pani I. 
przykłada dużą wagę do relacji z ludźmi, lecz w przedrozumieniu widać niewiele opisów relacji bohatera $\mathrm{z}$ innymi postaciami. Może to świadczyć, że również te relacje są dla niej ważne bardziej na poziomie działania niż uczuć.

\section{Interpretacja opowieści Pani J.}

\section{A) Przedrozumienie}

- Narrator i bohater opowieści zdają się bardzo łączyć ze soba, gdyż Pani J. często mówi o swoich uczuciach, a także wydaje się na nowo ich doświadczać w trakcie opowiadania. Jedynie w ostatnim fragmencie opowiadania bohater zdaje się niknąć, a uwaga narratora skupia się całkowicie na chorym mężu.
- Opowieść jest zdominowana przez uczucia. Zdaje się, iż to one spajają cały jej wątek, a poprzez ich obecność przeszłość splata się z teraźniejszością. Struktura opowieści nie jest wyznaczona chronologią. Narracja Pani J. wydaje się esencją tego, co ważne w jej życiu. Przeplata się w niej to, co dobre i radosne, z tym, co trudne i bolesne.

\section{B) Analiza formalna}

Narracja Pani J. trwała 75 minut. Przywołane w jej opowieści doświadczenia wraz z poświęconym im czasem przypisano do poszczególnych tematów. Obliczono wskaźnik procentowy udziału czasowego tematu w całej narracji (UT). Efekty tej analizy zawiera tabela 4.

Tabela 4. Kontekst doświadczeń i ich tematy w opowieści Pani J., wydarzenia im przypisane, czas im poświęcony $\left(\mathrm{CZ}_{\mathrm{t}}\right)$ oraz wskaźnik procentowy udziału tematu w narracji (UT)

\begin{tabular}{|c|c|c|c|c|}
\hline Kontekst & $\begin{array}{c}\text { Temat } \\
\text { doświadczeń }\end{array}$ & Wydarzenie & \begin{tabular}{|c|} 
Czas $_{\mathrm{t}}$ \\
(minuty)
\end{tabular} & $\begin{array}{l}\text { UT } \\
(\%)\end{array}$ \\
\hline \multirow{3}{*}{ osobowy } & strata & 1. Choroba i śmierć męża & 8 & 10.67 \\
\hline & sukces & 1. Praca jako księgowa & 5 & 6.67 \\
\hline & $\begin{array}{l}\text { walka o bli- } \\
\text { skie osoby }\end{array}$ & 1. Opieka nad mężem i synem & 2 & 2.67 \\
\hline \multirow{4}{*}{$\begin{array}{l}\text { egzysten- } \\
\text { cjalny }\end{array}$} & śmierć & 1. Choroba i śmierć męża & 8 & 10.67 \\
\hline & choroba & 1. Choroba i śmierć męża & 8 & 10.67 \\
\hline & $\begin{array}{l}\text { przyjazne } \\
\text { warunki } \\
\text { egzystencji }\end{array}$ & 1. Praca jako księgowa & 5 & 6.67 \\
\hline & samotność & 1. Doświadczenie starości i samotności & 2 & 2.67 \\
\hline \multirow{4}{*}{ społeczny } & relacje & 1. Relacja z synem & 2 & \multirow{2}{*}{6.67} \\
\hline & z rodziną & 2. Obecne relacje $\mathrm{z}$ rodziną & 3 & \\
\hline & $\begin{array}{l}\text { praca } \\
\text { z ludźmi }\end{array}$ & 1. Praca jako księgowa & 5 & 6.67 \\
\hline & $\begin{array}{l}\text { relacje } \\
\text { towarzyskie }\end{array}$ & 1. Relacja z koleżankami & 1 & 1.33 \\
\hline \multirow{6}{*}{ emocjonalny } & \multirow{3}{*}{ miłość } & 1. Choroba męża & 8 & \multirow{3}{*}{17.33} \\
\hline & & 2. Relacja z synem & 2 & \\
\hline & & 3. Obecne relacje $\mathrm{z}$ rodziną & 3 & \\
\hline & \multirow{3}{*}{ przyjaźń } & 1. Praca zawodowa & 5 & \multirow{3}{*}{10.67} \\
\hline & & 2. Odejście z pracy & 2 & \\
\hline & & 3. Relacja z koleżankami & 1 & \\
\hline $\begin{array}{l}\text { związany } \\
\text { z działaniem }\end{array}$ & $\begin{array}{l}\text { praca } \\
\text { zawodowa }\end{array}$ & 1. Praca jako księgowa & 5 & 6.67 \\
\hline
\end{tabular}


Tematem, któremu w opowieści poświęcono najwięcej czasu i do którego odnosi się największa liczba doświadczeń, jest miłość, a następnie przyjaźń. Tak więc wyraźnie widać, że Pani J. przykłada dużą wagę do bliskości z innymi ludźmi, zarówno należącymi do jej rodziny, jak i przypadkowo spotkanymi. W jej doświadczeniu ważne miejsce zajmują przeżycia związane z chorobą i śmiercią męża, co bardzo łączy się ze znaczeniem, jakie ma dla niej miłość. Kolejnym istotnym dla Pani J. tematem jest pra- ca zawodowa i płynące $\mathrm{z}$ niej doświadczenie sukcesu.

\section{C) Analiza powiazań między doświadczeniami a przeżyciami i refleksjami osoby}

W tabeli 5 przedstawiono metodą ilustracji najbardziej istotne wypowiedzi Pani J. odnoszące się do poszczególnych doświadczeń.

W tabeli 6 ukazano efekty wnioskowania na temat uczuć i znaczeń łączących się z poszczególnymi doświadczeniami Pani J.

Tabela 5. Wypowiedzi Pani J. ważne w kontekście danych doświadczeń

\begin{tabular}{|c|c|}
\hline Doświadczenie & Wypowiedzi \\
\hline $\begin{array}{l}\text { 1. Praca } \\
\text { zawodowa }\end{array}$ & $\begin{array}{l}\text { „To leży w moim charakterze, że jak coś robię, to robię dobrze”. „Pracowałam na } \\
\text { różnych stanowiskach z dużą odpowiedzialnością”. „Byłam ciągle lubiana”. „Były } \\
\text { takie przyjemne, miłe stosunki”. „I ja do nich mówię: «To wy jesteście, jak moje } \\
\text { dzieci»”. „Ja zawsze lubiłam swoją pracę i nie widziałam się gdzie indziej”. „Mia- } \\
\text { łam z tej pracy zadowolenie”. „Całe życie dochodziłam sama do wszystkiego”. }\end{array}$ \\
\hline $\begin{array}{l}\text { 2. Choroba } \\
\text { i śmierć męża; } \\
\text { choroba syna }\end{array}$ & $\begin{array}{l}\text { „To był taki ciężki okres, bo on był bardzo długo chory”. „Ten wyrok, który usły- } \\
\text { szeliśmy, to był straszny dla nas”. „No, ale do jednego i drugiego przychodziłam } \\
\text { uśmiechnięta i zadowolona”. „Nie mogłam pokazać jemu, temu choremu młodemu } \\
\text { człowiekowi, że ja tak to strasznie przeżywam, że jestem taka nieszczęśliwa z tego } \\
\text { powodu, bo on był bardziej nieszczęśliwy niż ja”. „No i po tym, po tej śmierci, po } \\
\text { tym wszystkim to taka pustka, ale pustkę tę zapełnił Marek [syn], no bo ludzie od- } \\
\text { chodzą, a życie toczy się dalej”. }\end{array}$ \\
\hline $\begin{array}{l}\text { 3. Aktualne } \\
\text { relacje } \mathrm{z} \text { rodziną }\end{array}$ & $\begin{array}{l}\text { "Cieszę się tymi swoimi wnukami”. „I to w tej chwili jest moją największą wartoś- } \\
\text { cią”. „Dzieci kochane, kochające, no naprawdę udana rodzina”., „Mam wspaniałą } \\
\text { rodzinę. No to już jest chyba najważniejsze po tym wszystkim”. }\end{array}$ \\
\hline $\begin{array}{l}\text { 4. Samotność } \\
\text { w starszym } \\
\text { wieku }\end{array}$ & $\begin{array}{l}\text { „Ale pomimo wszystko, to człowiek jest jednak trochę samotny”. „Tak jakoś braku- } \\
\text { je drugiej strony, bo człowiek jest już trochę słabszy”.,Dzieci najlepsze, ale mają } \\
\text { swoje sprawy”.,Małżeństwa powinny żyć razem do końca, bo w starszym wieku to } \\
\text { już potrzeba tej bliskości takiej na co dzień”. }\end{array}$ \\
\hline
\end{tabular}

Tabela 6. Uczucia i znaczenia łączące się z poszczególnymi doświadczeniami Pani J.

\begin{tabular}{|c|c|}
\hline Doświadczenie & Uczucia i znaczenia \\
\hline \multirow[b]{2}{*}{$\begin{array}{l}\text { 1. Praca zawo- } \\
\text { dowa }\end{array}$} & $\begin{array}{l}\text { Uczucia: akceptacja, samodzielność, pewność siebie, odpowiedzialność, przekona- } \\
\text { nie o własnych kompetencjach, swoboda, bezpieczeństwo }\end{array}$ \\
\hline & $\begin{array}{l}\text { Znaczenia: Praca ma bardzo duże znaczenie dla osobowego i emocjonalnego kon- } \\
\text { tekstu życia Pani J. Dawała jej poczucie kompetencji i osobistego spełnienia, a także } \\
\text { bliskości, bezpieczeństwa i przyjaźni. Praca jest dla Pani J. ważna, ponieważ dzięki } \\
\text { niej osiągnęła niezależność. To, że sama potrafiła dać sobie radę w życiu, daje jej } \\
\text { poczucie dumy i satysfakcji. }\end{array}$ \\
\hline \multirow[b]{2}{*}{$\begin{array}{l}\text { 2. Choroba } \\
\text { i śmierć męża; } \\
\text { choroba syna }\end{array}$} & Uczucia: odpowiedzialność, wrażliwość, bezradność, cierpienie, siła wewnętrzna \\
\hline & $\begin{array}{l}\text { Znaczenia: Przeżycia te odcisnęły się w wymiarze osobowym, emocjonalnym i eg- } \\
\text { zystencjalnym Pani J. Były to wydarzenia ogromnie dla niej trudne i bolesne, musia- } \\
\text { ła wykazać się siłą wewnętrzną i odpowiedzialnością za swoich bliskich. Po śmierci } \\
\text { męża ogromne znacznie miała dla niej obecność syna, który zapełnił pozostałą po } \\
\text { nim pustkę. }\end{array}$ \\
\hline
\end{tabular}




\begin{tabular}{|c|c|}
\hline Doświadczenie & Uczucia i znaczenia \\
\hline \multirow[b]{2}{*}{$\begin{array}{l}\text { 3. Obecne } \\
\text { relacje } \mathrm{z} \text { rodziną }\end{array}$} & Uczucia: akceptacja, więź, radość, sens życia \\
\hline & $\begin{array}{l}\text { Znaczenia: Rodzina zajmuje ważne miejsce w życiu Pani J., w aspekcie emocjonal- } \\
\text { nym i egzystencjalnym. Sprawia, iż czuje się kochana. Dostarcza jej dużo radości. } \\
\text { Dzięki niej czuje, że odniosła w życiu sukces, który wynagrodził jej cierpienia. }\end{array}$ \\
\hline \multirow{2}{*}{$\begin{array}{l}\text { 4. Samotność } \\
\text { w starszym } \\
\text { wieku }\end{array}$} & Uczucia: smutek, tęsknota, poczucie braku \\
\hline & $\begin{array}{l}\text { Znaczenia: Pani J. mimo obecności kochającej rodziny i licznych relacji towarzy- } \\
\text { skich doświadcza braku bliskiej osoby, jaką był jej mąż. }\end{array}$ \\
\hline
\end{tabular}

\section{D) Synteza etapu B i C}

Na podstawie etapu B zaobserwowano, że dla Pani J. ważne znaczenie mają relacje z bliskimi ludźmi, a także praca zawodowa, jak też, że w jej doświadczeniu bardzo istotne miejsce zajęła choroba męża. Dzięki etapowi $\mathrm{C}$ zobaczono, że miłość i relacje z rodziną dają Pani J. radość, a także są dla niej ważne w wymiarze egzystencjalnym, dostarczając poczucia sensu i będąc wynagrodzeniem cierpienia, jakie ją spotkało w życiu. Choroba męża była dla Pani J. ważna nie tylko ze względu na miłość do niego, ale także dlatego, że wymagała znalezienia w sobie wewnętrznej siły, by móc być dla niego wsparciem. W pracy zawodowej dla Pani J. istotne było poczucie kompetencji i sukcesu, ale także przyjazne stosunki i życzliwa atmosfera.

\section{E) Synteza etapu $D$ i A}

Już w przedrozumieniu zaobserwowano, iż dla Pani J. ważne są uczucia. Pozostałe etapy interpretacji potwierdziły to spostrzeżenie.

\section{Weryfikacja poprawności interpretacji}

Poprawność interpretacji została sprawdzona na podstawie opracowanych $\mathrm{w}$ tym celu, zindywidualizowanych ankiet (zał. 1 i 2). Stopień zgodności opinii Pani I. z interpretacją badacza wyniósł: $\mathrm{SZI}=94.5 \%$ (zgodność bardzo dobra). W wypadku ośmiu stwierdzeń zaznaczyła ona cyfrę 5, tj. „Całkowicie się zgadzam”, a jedynie przy trzech zaznaczyła 4, tj. ,Zgadzam się”. Po wypełnieniu ankiety była bardzo zadowolona. Mówiła, że czuje, iż na postawie jej opowieści wyciągnięto daleko idące wnioski i wyrażała radość $\mathrm{z}$ faktu, że mogła je poznać.

Stopień zgodności opinii Pani J. z interpretacją badacza wyniósł: SZI = 94.4\% (zgodność bardzo dobra). W wypadku czterech stwier- dzeń Pani J. zaznaczyła cyfrę 5, a przy dwóch cyfrę 4. Komentując ankietę, wyraziła opinię, że przeprowadzająca badanie bardzo dobrze ją zrozumiała, oraz podkreśliła, jak ważna jest w jej odczuciu rodzina.

W tym miejscu należy dodać, iż w wypadku pozostałych ośmiu osób badanych, których wyników nie uwzględniamy w niniejszym artykule, stopień zgodności opinii badanego z interpretacją badacza był również bardzo wysoki i wynosił od $89.0 \%$ do $95.5 \%$.

\section{DYSKUSJA}

Każda z badanych jawi się poprzez swoją narrację jako niepowtarzalna osoba, nadająca osobiste znaczenia własnym doświadczeniom. Różnice między badanymi przejawiły się nawet na poziomie konstrukcji narracji. Pani I. toczyła swoją opowieść w porządku chronologicznym, a Pani J. zawarła w niej jedynie najważniejsze wydarzenia swojego życia. Dla obu Pań ważne są relacje z innymi ludźmi, ale dla każdej z nich oznaczają co innego. Pani J. odbiera je głównie na poziomie uczuć, natomiast dla Pani I. jest $\mathrm{w}$ nich istotny kontekst działania.

Zgodnie z założeniami antropologii filozoficznej człowiek poszukuje sensu w spotykających go wydarzeniach. Na początku opowieści Pani I. wspomniała o swoim gorzkim doświadczeniu, jakim jest dla niej pobyt w domu pomocy społecznej. Zarazem jednak dodała, powołując się na powiedzenie: „Ktokolwiek się urodził, umrzeć musi", iż w pewien sposób akceptuje to doświadczenie, doceniając, iż dane jej było żyć tyle lat. Podobnie Pani J., opowiadając o chorobie i śmierci męża, stwierdziła, że jej syn i wspaniała rodzina są wynagrodzeniem cierpienia, jakie ją spotkało. W opowieściach 
obu Pań można także zaobserwować sposób, w jaki realizowały w życiu swoją egzystencjalną wolność. Pani I., zaspokajając potrzebę zdobywania wiedzy, podejmowała nowe kierunki kształcenia, rezygnowała z tych, które jej nie odpowiadały. Natomiast Pani J. stwierdziła, iż mimo że wiele osób nie docenia zawodu, który wykonywała, bardzo się cieszy z tego wyboru.

W opowieściach widoczne jest rozróżnienie między działaniem ,ja przedmiotowego" i ,ja podmiotowego" w życiu osób badanych. W sytuacji choroby męża i syna Pani J., mimo doświadczanego cierpienia, potrafiła tak pokierować sobą, by stanowić wsparcie i pociechę dla swoich najbliższych. Także Pani I. w sytuacji śmierci męża nie pozwoliła, by dano jej zastrzyk uspokajający, w imię wyznawanej zasady, że należy trzeźwo podchodzić do życia. Na podstawie tych opowieści widać, iż ,ja podmiotowe" ma moc kontroli nad zachodzącymi w nim procesami psychologicznymi nawet w najtrudniejszych momentach życia.

Interpretacja obu narracji udokumentowała, zgodnie z teorią Landgrebe (1968), iż komunikowane przez człowieka znaczenia odnoszą się do próby zrozumienia przez niego własnego położenia wyznaczonego przez wydarzenia otaczającego go świata i przez jego własne wolne wybory i decyzje. Pani I. poświęciła bardzo dużo miejsca opisowi sytuacji w czasie wojny, a także warunkom życia w domu pomocy społecznej. Widać więc, iż w tych momentach na jej położenie miały wpływ niezależne od niej okoliczności zewnętrzne. Zarazem jednak Pani I. wspomniała, odnosząc się do obu tych sytuacji, o swoich próbach przeciwstawienia się nieprzyjaznym warunkom egzystencji. Podczas wojny istotnym znaczeniem było dla Pani I. nabycie sprytu, które umożliwiło jej zdobycie węgla od Niemców dla swojej rodziny, natomiast podczas pobytu w domu pomocy społecznej jej formą przeciwstawienia się była walka o utrzymanie samodzielności, a także poinformowanie gminy o nieuczciwości dyrektora. Te działania były wyrazem jej wolnej woli i podmiotowości wobec warunków, na które nie miała wpływu. Również w opowieści Pani J. można zaobserwować próbę zrozumienia swego zmieniającego się położenia. Mówiąc o chorobach męża i syna, które były zdarzeniami całkowicie niepodlegającymi jej kontroli, Pani J. opowiada o swoim wysiłku zachowania zewnętrznej pogody, dzięki której mogła być wsparciem dla bliskich.

Prezentowane badania wydają się również potwierdzać tezę Ricoeura (1992), iż formułowanie i komunikowanie znaczeń zachodzi poprzez dialog z drugim człowiekiem. Obie Panie wielokrotnie odwoływały się w trakcie swojej opowieści do osoby badającej. Tłumaczyły jej różne rzeczy, używały sformułowań takich, jak „rozumiesz”, „widzisz”, ,wiesz”, a nawet zadawały jej krótkie pytania. Mówiąc, przejawiały także silne emocje. Obecność osoby słuchającej autonarracji wydaje się więc stanowić bardzo ważny czynnik motywujący osoby badane do ujawniania osobistych znaczeń.

Korzystne okazało się również pozostawienie badanym czasu na przemyślenie swojej opowieści. Badane Panie przygotowały się do drugiego spotkania, robiąc krótkie notatki. Widać więc, iż czas ten był im bardzo potrzebny na refleksję nad własnym życiem. Ponieważ w swoich opowieściach poruszyły ważne dla nich tematy i komunikowały istotne znaczenia, można uznać, iż treść przygotowanego bodźca narracyjnego, a także sposób przeprowadzania wywiadu były poprawne i sprzyjały ujawnianiu subiektywnych znaczeń. Nie wiadomo jednak, czy innego rodzaju metody nie skłoniłyby osób badanych do ujawnienia większej liczby znaczeń lub znaczeń o bardziej pogłębionej treści.

Zastosowana metoda interpretacji treści potwierdziła się, gdyż stopień zgodności interpretacji z opinią osoby badanej w obu wypadkach znacząco przekroczył 0.60. Istotną wskazówką poprawności tej metody była także pozytywna reakcja obu Pań na zaprezentowane im ankiety: sposób weryfikacji wyników spotkał się z akceptacją i uznaniem. Informacje zwrotne zawarte w ankiecie mogły być dla nich pewnego rodzaju wynagrodzeniem za czas poświęcony na badanie. Korzystne jest więc włączanie tego typu metod do procedury badań jakościowych.

Opracowana zgodnie z założeniami psychologii hermeneutycznej metoda interpretacji umożliwiła rozpoznanie części znaczeń komunikowanych przez podmiot, a zawartych w jego 
opowieści. Nie wiadomo, jak wiele $\mathrm{z}$ nich nie zostało rozpoznanych. Weryfikacja różnych metod interpretacji uwzględniająca większe próby byłaby konieczna w celu określenia ich skuteczności w odkrywaniu subiektywnych znaczeń zawartych w narracjach autobiograficznych.

\section{PRZYPISY}

1 Chodzi tu o wolność rozumianą w duchu egzystencjalnym, która jest potencjalnością wynikającą z kondycji człowieka. Nie da się jej wydedukować, racjonalnie uzasadnić, ale można ją odkrywać w różnych formach istnienia i działania człowieka (zob. Straś-Romanowska, 2004).

Całość materiału badawczego zostanie wykorzystana w innej, planowanej publikacji.

Wywiady przeprowadziła Magdalena Majewska, studentka psychologii Uniwersytetu Warszawskiego.

\section{BIBLIOGRAFIA}

Bartosz B. (2004), Ludzie chcą opowiedzieć swoją historię: konstruowanie rzeczywistości w narracji (przez pryzmat doświadczeń autobiograficznych). W: E. Dryll, A. Cierpka (red.), Narracja. Koncepcje i badania psychologiczne, 229-240. Warszawa: Wydawnictwo Instytutu Psychologii PAN.

Cierpka A. (2013), Tożsamość i narracje w relacjach rodzinnych. Warszawa: ENETEIA.

Denzin N.K. (1990), Reinterpretacja metody biograficznej w socjologii: Znaczenie a metoda w analizie biograficznej. W: J. Włodarek, M. Ziółkowski (red.), Metoda biograficzna w socjologii, 55-62. WarszawaPoznań: Wydawnictwo Naukowe PWN.

Dilthey J. (1982), Pisma estetyczne. Warszawa: Wydawnictwo Naukowe PWN.

Dryll E. (2004), Homo narrans - wprowadzenie. W: E. Dryll, A. Cierpka (red.), Narracja. Koncepcje i badania psychologiczne, 7-20. Warszawa: Wydawnictwo Instytutu Psychologii PAN.

Dryll E. (2013), Wrastanie w kulturę. Transmisja narracji w wychowaniu rodzinnym. Warszawa: ENETEIA.

Elsbree L. (1982), The Rituals of Life: Pattern in Narratives. Washington: Kennikat Press.

Frye N. (1963), Fables of Identity. Studies in Poethic Mythology. New York: Harcourt Brace.

Gergen K., Gergen M. (2011), Narrative tensions: Perilous and productive. Narrative Inquiry, 20(2), 374-381. DOI: $10.1075 /$ ni.21.2.17ger.

Gorbaniuk O. (2016), Wykorzystywanie procedury sędziów kompetentnych w naukach społecznych i możliwości jej oceny psychometrycznej za pomocą narzędzi dostępnych w STATISTICA. https://media.statsoft.pl/pdf/ czytelnia/wykorzystywanie_procedury_sedziow_kompetentnych.pdf (dostęp: 10.05.2019).

Helling I.K. (1990), Metoda badań biograficznych. W: J. Włodarek, M. Ziółkowski (red.), Metoda biograficzna w socjologii, 20-34. Warszawa-Poznań: Wydawnictwo Naukowe PWN.

Hermans H.J.M, Hermans-Jansen E. (2000), Autonarracje. Tworzenie znaczeń w psychoterapii. Warszawa: Pracownia Testów Psychologicznych PTP.

James W. (1892/2002), Psychologia. Kurs skrócony. Warszawa: Wydawnictwo Naukowe PWN.

Kaźmierska K., Schütze F. (2013), Wykorzystanie autobiograficznego wywiadu narracyjnego w badaniach nad konstruowaniem obrazu przeszłości w biografii. Na przykładzie socjologicznego porównania narracji na temat życia w PRL-u i NRD. Przegląd Socjologii Jakościowej, 9(4), 122-139, www.przegladsocjologiijakosciowej.org (dostęp: 12.05.2019).

Krejtz K., Krejtz I. (2013a), Rzetelność w analizie treści. W: K. Stemplewska-Żakowicz, K. Krejtz (red.), Wywiad psychologiczny, t. 1, 217-230. Warszawa: Pracownia Testów Psychologicznych PTP.

Krejtz K., Krejtz I. (2013b), Wybrane statystyki zgodności między sędziami w analizie treści. W: K. Stemplewska-Żakowicz, K. Krejtz (red.), Wywiad psychologiczny, t. 1, 231-249. Warszawa: Pracownia Testów Psychologicznych PTP.

Kwiatkowska G.E. (1996), Wstęp do psychologii hermeneutycznej. Geneza, teoria, zastosowania badawcze. Lublin: Wydawnictwo UMCS.

Landgrebe L. (1968), Phänomenologie und Geschichte. Gütersloh: Gütersloher Verlagshaus G. Mohn. 
Markowska M. (2007), Interpretacja jako rozumienie w ujęciu Wilhelma Diltheya. Czasopismo Filozoficzne, 2, 58-74, http://www.czasopismofilozoficzne.us.edu.pl/pliki/nr_2/interpretacja_jako_rozumienie.pdf (dostęp: 11.05.2019).

Maruszewski T. (2011), Psychologia poznania. Umyst i świat. Gdańsk: GWP.

McAdams D.P. (1993), Stories we Live by: Personal Myths and the Making of the Self: New York, NY: William Morrow and Company, Inc.

Pervin, L.A., John, O.P. (1997). Osobowość - teoria i badania. Kraków: Wydawnictwo Uniwersytetu Jagiellońskiego

Radnitzky, G. (1970). Contemporary Schools of Metascience, 2nd ed. Copenhagen: Scandinavian University Books.

Ricoeur P. (1992), Filozofia osoby. Kraków: Papieska Akademia Teologiczna.

Riessman C.K. (2008), Narrative Methods for the Human Sciences. London: Sage Publications.

Schütze F. (2007), Biography analysis on the empirical base of autobiographical narratives: How to analyse autobiobiographical narrative interviews. European Studies on Inequalities and Social Cohesion, part one no $1 / 2,153-242$, part two no $3 / 4,5-77$.

Straś-Romanowska M. (1992), Los człowieka jako problem psychologiczny: podstawy teoretyczne. Wrocław: Wydawnictwo Uniwersytetu Wrocławskiego.

Straś-Romanowska M. (1997), Hermeneutyka w psychologicznych badaniach jakościowych. W: A. Gałdowa (red.), Hermeneutyka a psychologia, 143-156. Kraków: Wydawnictwo Uniwersytetu Jagiellońskiego.

Straś-Romanowska M. (2000), O metodzie jakościowej w kontekście rozważań nad tożsamością psychologii. W: M. Straś-Romanowska (red.). Metody jakościowe w psychologii wspótczesnej. Acta Universitas Wratislaviensis No 2263, 15-32. Wrocław: Wydawnictwo Uniwersytetu Wrocławskiego.

Straś-Romanowska M. (2004), Podmiotowość człowieka w badaniach narracyjnych. W: E. Dryll, A. Cierpka (red.), Narracja. Koncepcje i badania psychologiczne, 23-36. Warszawa: Wydawnictwo Instytutu Psychologii PAN.

Straś-Romanowska, M. (2010), Badania ilościowe vs jakościowe - pytanie o tożsamość psychologii. Roczniki Psychologiczne, 13(1), 97-105.

Straś-Romanowska M. (2016), Podmiot osobowy w świecie współczesnym. Psychologia Rozwojowa, 21(2), 15-25. DOI: 10.4467/20843879PR.16.007.5085.

Trzebiński J. (2002), Narracja jako sposób rozumienia świata. Gdańsk: GWP.

Uchnast Z. (1983), Humanistyczna orientacja w psychologii osobowości. Lublin: Roczniki Wydawnicze KUL.

Żurko M. (2004), Rekonstrukcja poczucia tożsamości na podstawie narracji: Propozycje interpretacji tekstu autobiograficznego. W: E. Dryll, A. Cierpka (red.), Narracja. Koncepcje i badania psychologiczne, 220226. Warszawa: Wydawnictwo Instytutu Psychologii PAN. 


\section{ZAŁĄCZNIK 1.}

\section{Ankieta poprawności interpretacji [opowieść Pani I.]}

Na podstawie Pani opowieści próbowałam zrozumieć, co jest dla Pani ważne w życiu. Być może popełniłam jakiś błąd i źle Panią zrozumiałam. Chciałam Panią prosić, by ustosunkowała się Pani do rezultatów mojej pracy. Ponieważ to Pani najlepiej wie, co jest dla Pani ważne, więc każde z poniższych zdań może Pani uznać za niepoprawne. Szczerość Pani odpowiedzi umożliwi mi krytyczne podejście do mojej pracy. Proszę o ustosunkowanie się do poniższych zdań poprzez zaznaczenie kółkiem wybranej odpowiedzi:

1 - Całkowicie się nie zgadzam

2 - Nie zgadzam się

3 - Trudno powiedzieć

4 - Zgadzam się

5 - Całkowicie się zgadzam

1. Dzieciństwo było dla mnie ważne, ponieważ w tym okresie byłam szczęśliwa i doświadczyłam miłości rodziców.

$$
1 \ldots . .2 \ldots . . .3 \ldots . . \ldots . .5
$$

2. Dzieciństwo było dla mnie ważne, ponieważ w tym okresie nauczyłam się tego, co jest ważne w życiu.

$$
1 \ldots . .2 \ldots . .3 \ldots . . . . . .5
$$

3. W czasie wojny ważne było dla mnie to, że umiałam znaleźć w sobie siłę, odwagę i spryt, by jakoś sobie radzić $\mathrm{z}$ tymi trudnymi warunkami.

$$
1 \ldots . .2 \ldots . . . . . . .4 \ldots . .5
$$

4. Przykładam dużą wagę do tego, kiedy widzę, że wokoło mnie dzieje się jakaś niesprawiedliwość.

$$
1 \ldots . .2 \ldots . .3 \ldots . . . . . .5
$$

5. W życiu ważne jest dla mnie to, by być aktywnym, szczególnie w trudnych dla mnie sytuacjach.

6. Nauka była dla mnie ważna, ponieważ byłam ciekawa świata i chciałam poznać dużo nowych rzeczy.

$$
1 \ldots . .2 \ldots . .3 \ldots . . . . . .5
$$

7. Moja praca była dla mnie ważna, ponieważ dzięki niej czułam się kompetentna i pewna siebie.

$$
1 \ldots . .2 \ldots . .3 \ldots . . . . . .5
$$

8. Pomaganie ludziom i praca z ludźmi były dla mnie trudne, ale mimo to uważam, że nadawały sens mojemu życiu.

$$
1 \ldots . .2 \ldots . .3 \ldots . . . . . .5
$$

9. W życiu ważne było dla mnie to, by bronić siebie i swoich przekonań.

$$
1 \ldots . .2 \ldots . .3 \ldots . . . \ldots .5
$$

10. W moim małżeństwie ważne było dla mnie wzajemne wsparcie i zrozumienie.

11. W obecnym okresie ważne jest dla mnie to, by być samodzielną i aktywną w warunkach, które budzą mój sprzeciw. 


\section{ZAŁĄCZNIK 2.}

\section{Ankieta poprawności interpretacji [opowieść Pani J.]}

Na podstawie Pani opowieści próbowałam zrozumieć, co jest dla Pani ważne w życiu. Być może jednak popełniłam jakiś błąd i źle Panią zrozumiałam. Chciałam Panią prosić, by ustosunkowała się Pani do rezultatów mojej pracy. Ponieważ to Pani najlepiej wie, co jest dla Pani ważne, więc każde z poniższych sformułowanych przeze mnie zdań może Pani uznać za całkowicie niepoprawne. Szczerość Pani odpowiedzi umożliwi mi krytyczne podejście do mojej pracy i jej poprawę. Proszę o ustosunkowanie się do poniższych zdań poprzez zaznaczenie kółkiem którejś z odpowiedzi:

1 - Całkowicie się nie zgadzam

2 - Nie zgadzam się

3 - Trudno powiedzieć

4 - Zgadzam się

5 - Całkowicie się zgadzam

1. W życiu bardzo ważne są dla mnie bliskie relacje z innymi ludźmi, a w szczególności miłość w mojej rodzinie.

$1 \ldots . .2 \ldots . .3 \ldots . . . . . .5$

2. Moja praca była dla mnie ważna, ponieważ dzięki niej czułam się odpowiedzialna i kompetentna.

$$
1 \ldots . .2 \ldots . . .3 \ldots . . . . .5
$$

3. W pracy ważne było dla mnie także to, iż dobrze się tam czułam i byłam w przyjacielskich stosunkach z tymi, którzy ze mną pracowali.

$$
1 \ldots . .2 \ldots . . . . . .4 \ldots . .5
$$

4. Choroby męża i syna były dla mnie bardzo trudne, ale ważne było dla mnie wtedy to, by być silną i stanowić dla nich wsparcie.

$$
1 \ldots . .2 \ldots . .3 \ldots . . . . . .5
$$

5. Moja rodzina jest dla mnie ważna, ponieważ sprawia, że czuję się kochana i dostarcza mi dużo radości.

$1 \ldots . .2 \ldots . . . . . .4 \ldots . .5$

6. Moja rodzina jest dla mnie ważna, ponieważ jest naprawdę udana i stanowi pewnego rodzaju wynagrodzenie za trudności i smutki, których doświadczyłam w życiu. 